\title{
Lunar Imagery and Traditional Mythology in I. Kalynets' Poetry
}

\author{
Tetiana Oleksandrivna Tsepkalo
}

Lecturer, Department of Linguistics, Faculty of Philology and Journalism, Kherson State University, 27, Universytetska Str., Kherson, 730oo, Ukraine. E-mail: tanuysya@ukr.net

Received May 26, 2016; Revised July 21, 2016; Accepted July 30, 2016; Published August 18, 2016

\begin{abstract}
This article analyzes the lunar mythologem's features in the poetic works of the Ukrainian poet Ihor Kalynets in terms of traditional Slavonic concepts and world mythological traditions. This work also explores the myth poetics of the writer, his ideological continuum and specificity of individual author's myth creation based on the image of the Moon. This also includes an explanation of the said mythological concept as well as its role in the formative process of the myths. The mythologem of the Moon in Ihor Kalynets' poetry embodies the author's philosophical and social views via metamorphic manifestations. The relevance of the topic derives both from the lack of thorough analysis and the necessity for systematic study of the Moon's mythologem in Ukrainian literature in general and in poetry in particular. Synthesis of pagan and Christian thoughts is inextricably intertwined in the author's artistic models of the universe and is peculiar to individual aesthetic system, so that understanding and interpretation of the author's approach to depict the archetypal image of the Moon is one of the major issues of the modern Ukrainian literature.
\end{abstract}

Keywords: mythologem, the image of moon, worldview, myth poetics, myth creation, mythic mentality.

\section{Introduction}

The literary science and psychological researches of the $20^{\text {th }}$ and $21^{\text {st }}$ centuries offer rather a broader explanation for mythologism, guided by the archetypal analysis of the literary work based on K. G. Jung's analytical psychology (Jung, 1997), who treated archetypes as an inherited biologically images of the Collective Unconscious in the human soul's structure. N. Frye (Frye, 2007) described the literary archetype theory based on a combination of analytical psychology and the ritual-mythological concept. He defined archetypes as the settled models of subjects, ideas, motives and even literary genres. The archetype in terms of mythology was also investigated by M. Eliade (Eliade, 1996), who believed both the archetype and the myth to be the same link of human cultural evolution that unites the modern and the principles of the archaic world-views. The theory of archetypes was also influenced by the concept of invariance and interaction of form and content of A. Veselovskij (Veselovskij, 1959) and by the "sensual" concept of mythological consciousness of Lévi-Strauss, a representative of structuralist school (LeviStrauss, 2000). In his philosophical concept, A. F. Schelling (Schelling, 1998) brought the archetype doctrine to a completely new level, noting that cultural evolution forms a coherent process of universal prototypes functioning.

(c) AesthetixMS 2016. This Open Access article is published under a Creative Commons Attribution Non-Commercial 4.0 International License (http://creativecommons.org/licenses/by-nc/4.o/), which permits non-commercial re-use, distribution, and reproduction in any medium, provided the original work is properly cited. For citation use the DOI. For commercial re-use, please contact editor@rupkatha.com. 
Mythological images that reproduce ancient outlook are important both for the literary formation of myths, and for understanding of the surrounding reality. O. Polysayev notes that

“... mythical images are primarily aimed at establishing harmonious relations with the world, overcoming its hostilities and anxiety, as well as suppressing inherent fears that overflow human consciousness with horrors of misapprehension; they are also aimed at settling the communal life. The latter originates not only from explanation of an established order, but also from myth-based elaboration of a behavioral example to be rooted as a norm thanks to implementing mythical legends in rituals, which results in uniting people in certain communities by virtue of their practical, collective actions" (Polysayev, 2008, p. 12).

This statement allows to conclude that the mythological image is produced by a people's creative genius and is an inherent part of ethnic consciousness. M. Steblin-Kamensky confirms this thought: "(...) the myth is not merely images that have emerged in a certain individual's consciousness, but, rather, the images expressed with the word owned by the whole collective" (Steblin-Kamenskij, 1976, p. 87). Achievements of the world literature brilliantly demonstrate that myth embodies common cultural accomplishments, that different nations may have similar myth concepts, that numerous ontological notions and spiritual constants are common to all nations. Therefore, myth is a universal, common cultural, comprehensive modus existendi, which has preserved its relevance for many centuries and is yet relevant nowadays, being reproduced in its modern invariants. Common or similar subjects, images, concepts, symbols pertaining to different nations and times can be evidences of actually functioning traditional subject-matters present in belle-lettres and in oral tradition.

Modern literary scholars accurately explain reasons for the writer to directly address mythological images, motives, plots, etc. A. Hurduz links literary use of mythological structures with the "intent to implement new interpretation of mythological narration, to affirm the myth (or its elements) in the modern world, to describe modern realities in a mythological context and to 'universalize' them" (Hurduz, 2008, p. 19). A. Niamtsu specifies the myth formation functions by claiming that the author turns to legends and mythological material in "...an attempt to experience this past in a new, modern way, that is, to comprehend it in a completely different spiritual context, to find and to isolate deep communications and mutual dependence of the ages separated from each other, to simulate the difference of ethical potentials formed by inconsistent dynamics of the social advancement." (Niamtsu, 2008, p. 113)

The figurative system of the author's works is only one of his/her myth-poetry components. However, not each literary image may be perceived as a mythological one, as the latter is able to affect the reader's consciousness, to reveal secrets of the universe formation, to explain ontological categories and to display people's world-view stances. Ancient beliefs have been transformed into a widely accepted ontologically-based figurative system. A. Bilokobylsky emphasizes that the primitive man perceived the reality by means of ontologically consistent images:

“The myth attributes certain importance to this reality's objects by means of various classifications and rituals, and, thereby, it allocates them to the mythical subject. Being correlated to the ontological myth, to spatial and temporal "reference points", the object, thus, is rendered firm in the general order of life and acquires its ontological status. Hence, the mythical ontology conceives a new element of the reality, which exists only within this ontology" (Bilokobylskyi, 2004, p. 97). 
Due to such variegated and broad functionality of the myth, we can affirm that an act of creativity is the process of myth reproduction, interpretation and transformation. Myth is revealed in a masterpiece in various manners: standalone, veiled, mediated or metamorphic, but it is always there.

\section{Method}

The main method of our research is based on ritual and mythological approaches that investigate the reproduction of the ancient mythological image of the Moon in the poetic works of the famous Ukrainian poet Ihor Kalynets. This investigation combines a philosophical and a literary approach, which provides an analysis of specific poetic tools with formal method. The comparison of the $2 \mathrm{O}^{\text {th }}$ century Ukrainian writer's world-view to the ancient beliefs of the Slavic people on the Moon mythologem is carried out by means of a comparative and typological method. Historical, cultural, critical, archetypal and psychoanalytic methods have been applied, as well.

\section{Discussion}

Ihor Kalynets is a famous Ukrainian poet, writer, Professor Emeritus of Ivan Franko Memorial Lviv National University. Before 1980s, he was little known as a writer. His masterpieces, representing his national viewpoints, had been scarcely published, since their content opposed the political regime of the Soviet Union. In 1972, because of his own political views, I. Kalynets was arrested and deported to strict-security camps for six years, and then to Northern Ural and Trans-Baical area exile for three more years. Ihor Kalynet's poetic works may be divided into 17 collections, into two parts: 9 books written before his arrest, and 8 books written during his imprisonment and exile terms. Due to the political situation, only two of his books had been formally published in Ukraine before 1991, while his other books were distributed as clandestine copies. Literary critics consider I. Kalynets to be the founder of Ukrainian Neo-Baroque. His poems are distinguished by textual stylizations, extraordinary formal ingenuity, knowledge, sarcasm, concentration and gradation of images, scarcity of semantic tools, short elliptical phrases shift, etc.

The archetypal image of the Moon in poetic works by Ihor Kalynets is noted by specific metamorphoses and extraordinary manifestations. Numerous mythological transformations of the lunar image emphasizes inexhaustibility of the Ukrainian poet's mythological thinking. For example, in the poem "Masha" from the "Fire of Kupalo book", the celestial object is compared to a tax collector:

"We pay an everlasting rent for one kiss to the white-buckwheat Moon and gold heavens."

(Kalynets, 2008, p. 27). [translations by Tetiana Tsepkalo]

Defining the Moon to be white-buckwheat is the author's neologism deriving from an existing syntagm of "white buckwheat", which is based on association of comparison by color. The poet employs an approach to emphasize the infinity of the universe and eternity in general, and the Moon's in particular, combining private space with the macrocosm.

In the poem "Ardent Night" from the same book, the image of the Moon interferes with human life, as well, by watching over terrestrial events and reacting to them:

"The god of love has lit the pipe of ecstasy, 
he burned the innocence's white wings with covetousness.

That night, desirous women longed for affection,

Young ladies' faces blushed with shame

Warbling bodies merged into harmony,

Skirts clapped over hedges.

The jealous Moon

Covered all gates in the village with green tar, that night." (Kalynets, 2008, p. 28).

The ecstatic picture, elaborated by the author in the mythological poetics course, is developed dynamically and slows down only at the end, when the Moon's reaction to that night's events, whereof it witnesses, becomes described. Personification of an astral image is reduced here to the Moon's capability to watch people and to imperceptibly interfere with terrestrial life, without taking part in the orgy, though. A. Potebnya considers personification as an important element both of a mythological and a scientific thinking:

"An essential feature of personification is its being always inferior to the depth of its founder's mind. In other words, the mind that creates personification is capable to abstract a bit different circumstances, it has specific scientific thinking that is expressed by personification" (Potebnia, 1989, p. 483).

In his "Perun" poem, Ihor Kalynets describes a night star the witness of an apocalypse:

"Covered with smoke, the Tithe Church and a dozen of others -

May they bristle against God, may they go to hell!

The Moon licks rubbish heaps with its green tongue -

He is a Rahman witness of the pagan apocalypse." (Kalynets, 2008, p. 41).

By opposing Christian beliefs to the paganism, the Ukrainian poet gives an allegorical picture of burning of the churches (the Tithe Church, the first stone church in Kievan Rus'), which symbolizes the victory of paganism over Christianity ("The days of yore come back from among the ages of shard (...)" (Kalynets, 2008, p. 41). The pagan god Perun wins his victory by virtue of his ability to burn all evil (Bahniuk, 2010, p. 26), which is hereby attributed to the Christian Orthodox religion. Here, the lunar image is shown not only as being an imperceptible eyewitness to events, but as such that cleans outcomes of the disaster. However, the author does not give any clue, which religion the Moon favors.

Opposed to this, the poem "Cows" (dedicated to I. Marchuk) depicts this celestial body as an adept at paganism, which is clearly reflected throughout the poem, from the very beginning to the end:

"Your black cows, Iane, like bulls

They bear the primeval night majestically on their horns.

The bloody Moon's millstone

Crushed our land by paganism". (Kalynets, 2008, p. 74).

In this context, the paganism is pulled to the forefront and is even extolled. However, it is depicted with negative connotations in this work, as the metaphor of this text carries the concept of ruining the land. Here, the Moon appears in the form of a bloody millstone that crushes the land with paganism. Thus, the Moon and the land are opposed to each other, and, subsequently, paganism and Christianity are opposed to each other at the subtextual level, respectively. The author dedicated this poem to the famous Ukrainian artist Ivan Marchuk, being inspired by his 
individual style of his works (so-called 'pliontanizm' or 'weaverism'), as his works are made with a technique that looks like clews of weaving threads, bearing a special hidden meaning in their cobwebs.

The surrounding reality of the mythological text structure is described, explained and transformed into an individual mythological paradigm. The masterpiece encompasses all metamorphoses of both the real and the imaginary world, building up a complex system of mythological elements, scheme, image and motives, which are translated by the author on a subconscious level. Therefore, the myth-poetic analysis of the author's works allows for deep realization and interpretation of the author' perception of the world. It is very tempting to quote Zvarych:

"When a word is distanced from reality, it transforms into a text tool and designed to subsequently express the living life, provoked by constant experiencing of its unutterable meaning. The incapability of the word to reflect the essence of existence by virtue of the secondary reality, which is literature, is the core of the permanent conflict rooted in the very word. Hence, the particular reason for the word to become the art (verbal game) originates from its willingness to express its primary, existential essence, lost due of its functionality shift. Historicization of consciousness, linearity of time measuring, both implemented in the text by means of fable narrativity, emerge over the existential reality's text unity, dealing with it (this reality) as the main object of cognition. Many writers, who sensitively perceived the word's distancing from the entirety of the life's essence, evidenced the subtlety of underlying essential processes of spiritual human life" (Zvarych, 2003, p.12).

Although Ihor Kalynets emphasizes paganism in his poetic works, he widely employs Christian motives in many of his poems. Thus, in his "Carol" poem, the poet traditionally uses the biblical Gospel story about the birth of God's Son Jesus Christ:

"The boy is laying in the sheepfold,

Let us bring our gifts for the boy:

A little star, another little star

And the bright Moon

The Most Holy Mother wondered

She weeps over the Child in awe,

And a little star and a little star,

And the bright Moon.

We were going, oh, Our Lady, from Ukraine

And we picked a cluster of guilder-rose,

A little star, a little star

And a bright Moon”. (Kalynets, 2008, pp.331-332).

According to the biblical legend, three wise men brought gifts for the newborn Savior: gold, frankincense and myrrh (Bahniuk, 2010, p.148). However, in this poem, the gifts are the Moon and the stars, to directly emphasize the omnipotence of God's Son. This poem is stylized so as to simulate Ukrainian folk Christmas carols, which is evident from the creative rethinking of the apocryphal story and the refrains at the end of each strophe, thereby focusing the reader's attention on the astral images. The Moon and the stars appear here in diverse guises: as gifts for the Baby, as witnesses of the Savior's birth, as assistants to the Virgin Mary, as escorts for travelers, etc. 
The use of images of celestial bodies in winter calendar's ritual poetry is not accidental, since the winter is the time for celebrating their birth:

"When the Sun passes the central stars of Perun constellation (January 1), the birth of the Moon (New Moon), or Epiphany, is solemnly celebrated, and when the Sun leaves the last stars of this constellation, Dana - the water embodied - is born ( January 6). Hence, it appears that the Moon, the Sun and stars are all children, who had been born in the principal Ruthenian zodiac constellation of Svarog and constellation of the ancient idol Perun (Sagittarius)" (Znoiko, 2004, p.57).

Ihor Kalynets' poem “The Moon” from his book The Twelfth Sad Book details metaphoricallymythological description of the new Moon's appearance specifically during Epiphany, which is evidenced by the last strophe:

"The old Moon

Hardened with red bark

Like a pine

The old Moon

Creeping

Under its bark

We need to call for a woodpecker

From the forest

And the young Moon

Strikes with its horns

Like a billy-goat,

Made the old Moon

Feel chafe

From lying too long

On a cloud

And the young one

cannot sleep

He runs quickly

Throughout the sky

Somewhere there, the stars

sang their carols." (Kalynets, 2008, p.374).

The contrast between the old and the new Moon is symbolic, sacred, since both these images differ only by their interdependent phases of the same celestial body. Mysteries that take place in the night sky are logically superimposed on the Epiphany's celebration rites, associated with singing carols and a ritual leading a goat, as goat has been the lunar deity's sempiternal attribute (Znoiko, 2004,p.52). Here, the new Moon is symbolically compared with a billy-goat, with its semantic suggestion partially reflecting the elements of Ukrainian folk traditions and beliefs, in terms of the Ukrainian popular saying about the Orb of Night and stars: "The goat and its kids frisk on the field"(Voitovych, 2005, p.202). The importance of the new Moon's birth is also 
emphasized with such an artistic component as Schedrivka, or carol song, considered in Ruthenia to be a hymn exalting the Orb of Night (Znoiko, 2004,P.52). These carol songs were performed as a part of an Epiphany festivity celebration to honor the new Moon's birth. Reflecting the rite in the language, according to M. Stepyko, derives from the custom that adds a meaning to action and is the very meaning of the action, per se. (Stepyko, 1998, p.87). "Traditionally, celebration of Epiphany, or Generous Evening, was initiated in Ukraine by shepherds, who had associated themselves with the Moon, or Did (Didukh). The Ukrainian people used the Epiphany (Generous Evening) rite to commemorate their ancestors. Koza (goat) was a compulsory player of the Epiphany's Vertep (Ukrainian Christmas Crib Theater) play main role, thereby obviously coding certain historical events from the life of shepherds " (Kuievda, 2007, p.145).

The Slavs called the lunar deity Koliada or Vasyl (Znoiko, 2004, p.51). This is the reason why Ihor Kalynets, in his poem "Carol", when describing perception of Christmas holidays by a little girl, uses metaphoric image of the Moon on a subconscious level:

"Koliada came to little Zvenyslava

with a star gazer and a bag that fits in everything.

Zvenyslava teases her grandmother: give me

a Moon's honey cake from the night's Christmas-tree!

The bunnies rolled - like balls all in the snow -

And started to bend the Christmas tree for Zvenyslava.

And the Moon, of course, makes fun of all that,

For it is firmly tied to the golden thread." (Kalynets, 2008, p.39).

The attributes of Christmas holidays - the Christmas tree, decorations, presents, sweets, all of them are subjected to fairy transformation, extended to astral phenomena; they create a special mythological narrative with the national coloration. Here, the Orb of Night is both subjectified an animated, both being a Christmas tree decoration and being able to mock of the snow bunnies. This ambivalence of the lunar image interpretation creates a special semantic meta-message that reveals the author's implicit associations.

In Ihor Kalynets' "Poetic compositions about tiny people" from the book Coronation of a Scarecrow, Christian motives are explicitly expressed reflecting the ancient world-view of Ukrainian people:

"They never forget

Even the Sun's for its spots

They never forget

The moon's

Murder committed by brother

On brother

They would not forget the white star

For having been faded

Millions of years before us." (Kalynets, 2008, p.87).

Describing sins of all the celestial bodies, the author ascribes the most grievous sin to the Moon, who provided protection for fratricide. The biblical legend of fratricide is reproduced here according to the spiritual and genetic grounds of Ukrainian mythology: 
"By God's decree, neither water nor land could shelter the fratricide. But the Moon, contrary to the will of the Lord, gave the murderer a shelter, and bears the mark of Cain's sin ever since" (100 Most Famous Images, 2006, p.31).

The lack of punctuation creates the effect of forcing emotionally expressive meaning of the story. It is revealing that the author uses images of the entire luminaries triad in his work, following the archaic world-views: "The Moon is a part of the heavenly triplicity, the astral triad deified by the Slavs: the Moon, the Sun, the Stars." (Slavic World, 2008, p.44).

These images are interpreted alternatively in Ihor Kalynets' "Who You, Oh, Land..." from his book Vers Libre Sentence:

"You will pull

To the bottom

Of the star river

both the Moon and the Sun." (Kalynets, 2008, p.230).

In this composition, the author exalts the Earth opposing it to the universe, heaven, God, and even people. The Earth's power and strength are oppressed by her cosmic position, but they are exalted against people, countries, elements and astral bodies. The Sun and the Moon, thus, are not so important as the Earth; they appear weak and play a secondary role in the overall universe:

"The theory of myth creation as an active human attitude to nature and its alteration in fantasy has its own reasons, but apperception, i.e. the formation of people's sensory experience by association with human beings, is not a psychological process, per se, or an $a$ priori transcendental synthesis in terms of traditional Kantianism. Mythological apperception has real meaning. Fantasy, which ascribes the subjective properties to inanimate objects, is something more than just a "sensation", it is an active form of emotional reducing perception of nature only from the human point of view. It is a shadow of a human being in the nature that manifest his material practice." (Lifshyts, 1979, p.74)

In his poem "Seven", Ihor Kalynets successfully combines macrocosmic rhythms with microcosmic ones, describing one of the most important functions of the Moon, which is to affect the nature's fertility and fecundity,

“And the Moon's growth watches over women's wombs

Thou be completely lighted not waning

With all sounds of range

With all colors of the celestial arc

Having created creation cycle anew

In all of us." (Kalynets, 2008, p.475).

The continuous text without any punctuation mark that describes the specific manner of the author's writing produces the effect of chaos, which, nevertheless, conceals a certain profound meaning, as this fragment fully reflects ancient concepts of the world mythology. The ancient people associated symbolism of the Moon with the feminine essence, conception, fertility, and birth, with the full Moon regulating women ovulation in particular (O'Connell, 2009, p.120). Such a symbolism was accounted for the fact that "the moon cycle practically coincides with the female menstrual cycle” (O'Connell, 2009, p.120). The Ukrainian poet extends this Orb of Night's capability to controlling personal space and individual cycles of each human. 
Therefore, the myth analysis of art provides a detailed study of all myth elements as tools for revealing origins of the world-views and an individual world-view as well. Archetypal structures, such as archetypal images, mythologem, mytheme, mythological plots and motivesall closely interact with one another expressing the objective meaning of the archetype and performing axiological, world-view, cultural and integrative functions. Implementation of Ukrainian mythology in ceremonial folklore allows to represent ritual, custom and cult of mythological factors in the interpretation of archaic material, as well as development of metaphysical dimensions that are embodied mainly in mythological symbols. T. Shestopalova notes that the

"symbol, per se, concentrates existential unity both of national and universal. Symbol is a reproducer of the world-view poliphony, based on the aesthetic concepts specific for the given culture" (Shestopalova, 1999, p. 39).

This statement reveals direct connection with the mythology of symbol as the bearer of human world-view genomes.

Updating of the mythological critical approach to literary activity necessitates understanding the primary sources of collective aesthetic consciousness and analysis of individual author's myth creation. The myth-creation process results in the awareness of cultural and ideological origins of spiritual tradition, the fundamentals of which are based on the principles of pagan and primitive Christian world-views.

\section{Conclusions}

Myth analysis reveals concealed aspects of the author's consciousness, while study of certain myths allows exposing artist's creative potential. The analysis of the Moon's mythologem in the lyrics written by Ihor Kalynets gives a fairly broad understanding of the author's myth creation principles. However, an exhaustive reproduction of his artistic world-view requires a detailed study of the interaction of certain archetypal images and myth poetics of his creativity, as a whole. At present, we consider this task necessary and challenging.

I. Kalynets' poetry includes non-typical, unique features of multiple visual forms, shocking, challenging the existing tradition, associations, etc. In particular, it features pioneering methods on image and symbols too. His extraordinary perception of the astral bodies, his individual attitude to the surrounding world have been induced by the needs of contemporary culture, limited by the political regime of the USSR. The non-traditional interpretation of the world that employed certain mythologems, especially the lunar image, allowed for Ukrainians to look alternatively at their surrounding reality and conditions, imposed on them by the contemporary political regime, at the situation, where both an individual's personality and his or her creative potential had been leveled. As a result, I. Kalynets managed to substantiate the importance of struggle for the country's independence with the Ukrainian readers. While openly expressing his position on the contemporary political situation, the writer courageously declared that he was a Ukrainian and kept introducing culture of his own land to other countries of the world. 


\section{References}

100 the most famous images of Ukrainian mythology. (2006). Kyiv: LTD“Autograph”, LTD“Book House"Orpheus".

Bahniuk, A.L. (2010). Symbols of Ukrainians: Art and information guide. Ternopil: Educational book Bogdan.

Bilokobylskyi, A. (2004). From science to myth. Ontological studies. Donetsk: Apeks.

Eliade, M. (1996).Aspects of myth. Moscow.

Frye,N. (2007).Anatomy of criticism.Moskow: Direct Media.

Hurduz, A. (2008).Myth poetic paradigm in Ukrainian and West European prose about the earth in the late XIX - the first third of the twentieth century. Mykolaiv: Publishing house of P. Mohyla MSHU.

Jung, K.-H. (1997). Soul and myth: six archetypes.Moscow-Kyiv: ZAO "Sovershenstvo"-"Port-Royal”.

Kalynets, I. (2008).Poems. Lviv: LA "Piramida”.

Kononenko, O.A.Slavic world. Illustrated Dictionary of mythological ideas, beliefs, rituals, legends and their responses in folklore and later customs of Ukrainians, Slavic brothers and other peoples. Kyiv: Association of businesscooperation "Ukrainian international cultural Center".

Kuievda,V. (2007). Mythological sources of Ukrainian ethnocultural model: the psychological aspect. Donetsk: Ukrainian Culturological Center, Donetsk branch.

Levi-Strauss, C. (2000). Structural Anthropology. Kyiv: Osnovy.

Lifshyts,M. (1979).Mythology ancient and modern. Moscow: Iskustvo.

Niamtsu, A.E. (2008).Transformational context oflegendary and mythological tradition.Bulletin of Odessa National University. Volume 13. Issue 7. Philology: Literature Study. Odessa: Astroprint.

O’Connell, M., \&Airey, R. (2009). Signs and Symbols: Illustrated Encyclopedia. Moscow, M: Eksmo.

Polysayev, A.P. (2008). Architectonics of modern myth. Ternopil: Aston.

Potebnia,A.A. (1989).Word and myth. Moscow: Pravda.

Schelling, F.V.(1998). Introduction to Philosophy of mythology. (Vol.2.). Moscow.

Shestopalova, T. (1999).Correlation of concepts of "archetypal image - mythologem - symbol - myth" (on the example of poetry by Pavlo Tychyna). Kyiv: Stylos.

Steblin-Kamenskij, M.I. (1976)Myth. Leningrad: Nauka.

Stepyko, M.T. (1998).Existence of ethnos: origins, modernity and prospects (philosophical and methodological analysis). Kyiv: "Znannia”.

Veselovskij, A.N. (1959). Unpublished chapter from "Historical poetics" by A.N.Veselovskij. Russian literature, 3 .

Voitovych,V.M. (2005).Ukrainian mythology(2nd ed.).Kyiv: Lybid.

Znoiko,O.P.(2004) Myths of the Kievan earth and ancient events(2nd ed.). Kyiv: Molod.

Zvarych,I.M. (2003).Mythological paradigm of creative thinking.(Unpublished master's thesis). Ternopil state pedagogical university of the name is V. Gnatyuk. 